\title{
Bioactive gel-glasses with distinctly different compositions: Bioactivity, viability of stem cells and antibiofilm effect against Streptococcus mutans
}

\author{
Renato L. Siqueira ${ }^{\mathrm{a}, *, 1}$, Natasha Maurmann ${ }^{\mathrm{b}}$, Daniela Burguêz ${ }^{\mathrm{b}}$, Daniela P. Pereira ${ }^{\mathrm{b}}$, Alessandra N.S. Rastelli ${ }^{\mathrm{c}}$, \\ Oscar Peitl ${ }^{\mathrm{a}, 1}$, Patricia Pranke ${ }^{\mathrm{b}, \mathrm{d}}$, Edgar D. Zanotto ${ }^{\mathrm{a}, 1}$
}

\footnotetext{
a Laboratório de Materiais Vitreos, Departamento de Engenharia de Materiais, Universidade Federal de São Carlos, São Carlos, SP, Brazil

b Laboratório de Hematologia e Células-tronco, Faculdade de Farmácia, Universidade Federal do Rio Grande do Sul, Porto Alegre, RS, Brazil

${ }^{\text {c } F a c u l d a d e ~ d e ~ O d o n t o l o g i a, ~ D e p a r t a m e n t o ~ d e ~ O d o n t o l o g i a ~ R e s t a u r a d o r a, ~ U n i v e r s i d a d e ~ E s t a d u a l ~ P a u l i s t a, ~ A r a r a q u a r a, ~ S P, ~ B r a z i l ~}$
}

${ }^{\mathrm{d}}$ Instituto de Pesquisa com Células-tronco, Porto Alegre, RS, Brazil

\section{A R T I C L E I N F O}

\section{Article history:}

Received 27 September 2016

Received in revised form 23 November 2016

Accepted 7 March 2017

Available online 9 March 2017

\section{Keywords:}

Bioactive glass

Sol-gel

In vitro bioactivity

Cell viability

Stem cells

Biofilm

\begin{abstract}
A B S T R A C T
In this study, an evaluation was performed to determine the in vitro bioactivity, viability of stem cells, and antibiofilm effect against Streptococcus mutans of two bioactive gel-glass $60 \mathrm{SiO}_{2}-36 \mathrm{CaO}-4 \mathrm{P}_{2} \mathrm{O}_{5}(\mathrm{BG}-\mathrm{A})$ and $80 \mathrm{SiO}_{2}-15 \mathrm{CaO}-5 \mathrm{P}_{2} \mathrm{O}_{5}$ (BG-B) compositions. Both materials were bioactive and undergo the formation of hydroxycarbonate apatite (HCA) on their surfaces when immersed in simulated body fluid (SBF) after $12 \mathrm{~h}$, but the BG-A composition showed a more significant formation rate. The $\mathrm{pH}$ variation of the samples during the test in SBF indicated that an abrupt change had occurred for the BG-A composition within the first few hours, and the $\mathrm{pH}$ was subsequently maintained over time, supporting its stronger antibacterial effects against S. mutans. For the in vitro viability test using mesenchymal stem cells (MSCs), the BG-B showed significantly higher cell viability compared to the BG-A composition at concentrations of $0.125,1.25$ and $12.50 \mathrm{mg} / \mathrm{mL}$ for 2 days. These results indicated that the higher solubility of the BG-A glass favors bioactivity and antibacterial effects. However, as a result of rapid degradation, the increase in the concentration of ions in the cell culture medium was not favorable for cell proliferation. Thus, by varying the composition of glasses, and consequently their dissolution rate, it is possible to favor bioactivity, antimicrobial activity or stem cell proliferation for a particular application of interest.
\end{abstract}

(c) 2017 Elsevier B.V. All rights reserved.

\section{Introduction}

Bioactive glasses are synthetic materials, which sho|w highly positive interactions with hard and soft tissues [1-3]. The first bioactive glass, known worldwide for its trademark Bioglass ${ }^{\circledR}$, was invented by Professor L.L. Hench at the University of Florida in 1969 [4]. Its ability to form a mechanically strong bond with bone via the formation of a hydroxycarbonate apatite (HCA) layer on the glass surface after implantation in the body resulted in the concept of bioactive materials, which now constitute a very important class of new-generation, high tech materials.

The formation of the HCA layer on bioactive silicate glasses is now reasonably well understood $[1,4,5]$, but the biological interactions at the HCA-host bone interface are much less clear [2]. The adsorption of proteins, as well as other biological molecules on the HCA layer surface,

\footnotetext{
* Corresponding author.

E-mail address: rastosfix@ppgcem.ufscar.br (R.L. Siqueira).

${ }^{1}$ Center for Research, Technology and Education in Vitreous Materials (CeRTEV) www.certev.ufscar.br.
}

are highly complex and require significant further in-depth analysis to fully and conclusively understand the positive and negative effects of the numerous biomolecule adsorption-desorption processes at play [5]. On the other hand, osteoprogenitor cells appear to be attracted to the nanotopography and chemistry of the HCA layer and, perhaps more importantly, they respond to ionic dissolution products from the degrading bioactive glass, particularly to critical concentrations of biologically active soluble silica and calcium ions $[2,4,6]$. While the degradation and conversion of the glass into HCA continues over time, the released ions are responsible for the up regulation of genes associated with bone formation, including the cMyc-responsive growth-related gene, cell cycle regulators, apoptosis regulators, cell surface receptors and extracellular matrix regulators [4,5-9]. Furthermore, the antimicrobial activity associated with the release of ions in the surrounding medium is regarded as an additional benefit for clinical applications [2,6,10, 11]. These effects are dose-dependent and it is still a challenge for researchers from diverse areas to design and adjust the glass chemistry, making these glass matrices potential carrier systems for controlled therapeutic ion release to assist in tissue regeneration and antimicrobial activity. 
Due to controlled glass degradation, and consequently its ionic products released in physiological conditions that provide stimuli to several biological properties, in this study we evaluated the in vitro bioactivity, viability of stem cells, and antibiofilm effect against S. mutans of two bioactive gel-glass, which exhibit distinctly different chemical compositions. The use of sol-gel processing methods to obtain these materials led to the synthesis of bioactive glasses with greater textural and compositional variety than those attainable by melt-quenching. Therefore, the possibility of exploiting a much broader compositional range for bioactivity, cell behavior and antimicrobial activity using a low-temperature processing route is very attractive because these properties show a strong relationship with the glass dissolution rate, ion release and resulting $\mathrm{pH}$ environment.

\section{Materials and methods}

\subsection{Gel preparation}

Gel-derived glasses were synthesized as described elsewhere [12]. The nominal $60 \mathrm{SiO}_{2}-36 \mathrm{CaO}-4 \mathrm{P}_{2} \mathrm{O}_{5}(\mathrm{BG}-\mathrm{A})$ and $80 \mathrm{SiO}_{2}-15 \mathrm{CaO}-5 \mathrm{P}_{2} \mathrm{O}_{5}$ (BG-B) compositions by mol\% were chosen based on previously published studies related to the first bioactive gel-glasses [13] and the optimal chemical composition for the most rapid positive bio-response in osseous tissue regeneration, suggested by Malavasi and colleagues [14], using molecular dynamics simulations.

To obtain $50 \mathrm{~g}$ of glass, the preparation of BG-A gel involved hydrolysis and polycondensation reactions mixing $109.28 \mathrm{~mL}$ tetraethoxysilane (TEOS, $\left.\mathrm{Si}\left(\mathrm{OC}_{2} \mathrm{H}_{5}\right)_{4} 99 \%\right), 11.00 \mathrm{~mL}$ triethylphosphate (TEP, $\mathrm{OP}\left(\mathrm{OC}_{2} \mathrm{H}_{5}\right)_{3} 99.8 \%$ ) and $69.35 \mathrm{~g}$ calcium nitrate tetrahydrate $\left(\mathrm{Ca}\left(\mathrm{NO}_{3}\right)_{2} \cdot 4 \mathrm{H}_{2} \mathrm{O} 99 \%\right)$, provided by Sigma-Aldrich. The hydrolysis of TEOS and TEP was catalyzed by a solution of $\mathrm{HNO}_{3}(\mathrm{pH}=1)$ using the relationship: $\left[\mathrm{HNO}_{3}+\mathrm{H}_{2} \mathrm{O}\right] /[$ TEOS + TEP] $=12$. Starting with the hydrolysis of TEOS, the other chemicals were sequentially added to the reaction mixture in $60 \mathrm{~min}$ intervals while the mixture was maintained under constant stirring. The sol was poured into a polytetrafluoroethylene mold and stored for 3 days. At the end of this period, the gel was aged for 7 days at $70{ }^{\circ} \mathrm{C}$ and dried for additional 3 days at $150{ }^{\circ} \mathrm{C}$ before it was ground manually in an agate mortar and subsequently heat treated for $3 \mathrm{~h}$ at $700{ }^{\circ} \mathrm{C}$ for stabilization and to obtain the glass. The same synthesis procedure was employed for preparation of $50 \mathrm{~g}$ of the BG-B composition, using $141.90 \mathrm{~mL} \mathrm{Si}\left(\mathrm{OC}_{2} \mathrm{H}_{5}\right)_{4}$, $13.39 \mathrm{~mL} \mathrm{OP}\left(\mathrm{OC}_{2} \mathrm{H}_{5}\right)_{3}$ and $28.14 \mathrm{~g} \mathrm{Ca}\left(\mathrm{NO}_{3}\right)_{2} \cdot 4 \mathrm{H}_{2} \mathrm{O}$, respectively. The flowchart in Fig. 1 outlines the procedures established for particulate gel-glass preparations.

\subsection{Characterization of the glass powders}

\subsubsection{X-ray diffraction (XRD)}

X-ray diffraction was used to analyze the glass powders before and after the in vitro bioactivity test using a Rigaku Ultima IV X-ray diffractometer operating with $\mathrm{CuK} \alpha$ radiation $(\lambda=0.15418 \mathrm{~nm})$. The diffraction patterns were obtained in the $2 \theta$ range from 10 to $70^{\circ}$ in a continuous scan mode at $1^{\circ} / \mathrm{min}$.

\subsubsection{Fourier transform infrared (FTIR) spectroscopy}

Powder surfaces were assessed by FTIR using a PerkinElmer Spectrum GX spectrometer operating in reflectance mode with a spectral resolution of $4 \mathrm{~cm}^{-1}$ from 4000 to $400 \mathrm{~cm}^{-1}$. Spectra were collected as the mean of 40 scans.

\subsubsection{Scanning electron microscopy/microanalysis (SEM/EDS)}

The powders were morphologically characterized using SEM. A set of samples was selected and analyzed before and after immersion in SBF for different testing times. The samples were coated with an evaporated gold film and analyzed under an FEI Inspect S50 microscope coupled with an energy dispersive X-ray spectrometer (EDS), which allowed for qualitative chemical analysis of their surfaces. Discs of BGA and BG-B containing S. mutans biofilm were also analyzed using SEM after washing the samples in a sterile phosphate-buffered saline (PBS) solution and maintained in a $4 \%$ glutaraldehyde for $24 \mathrm{~h}$. Next, the biofilms were dehydrated in a graded ethanol series (50, 70, 90, and $100 \%)$, dried for $24 \mathrm{~h}$ and coated with gold film for analysis.

\subsection{In vitro bioactivity test}

The samples bioactivity was evaluated according to a recent method proposed by Technical Committee 4 (TC04) of the International Commission on Glass (ICG) [15]. The solution employed in this test is known as SBF (simulated body fluid) and is acellular, protein-free and has a $\mathrm{pH}$ of 7.40. Its ionic concentration versus human blood plasma is shown in Table 1.

The particulate samples were immersed in SBF using a ratio of $0.1 \mathrm{~g}$ glass to $50 \mathrm{mLSBF}$. Each sample was cleaned ultrasonically for $10 \mathrm{~s}$ in acetone and after drying immersed in polyethylene bottles containing SBF for $12,24,48,96$ and $168 \mathrm{~h}$. The systems were held under constant agitation at $37{ }^{\circ} \mathrm{C}$ in a shaker table, and at the end of each testing time, the samples were removed from the bottles by filtration (particle retention $>3 \mu \mathrm{m}$ ). The powder was washed with distilled water/acetone to terminate any surface reaction. After drying, all samples were analyzed to check for formation of a superficial HCA layer. The filtered solution was collected to determine the variations in the $\mathrm{pH}$ due to the partial glass dissolution in SBF during the test; each sample was performed in triplicate.

\subsection{Stem cell study}

\subsubsection{Stem cell isolation, maintenance and characterization}

Samples of deciduous teeth were obtained in collaboration with the Postgraduate Program in Pediatric Dentistry from the Universidade Federal do Rio Grande do Sul (UFRGS). The patients' parents/guardians
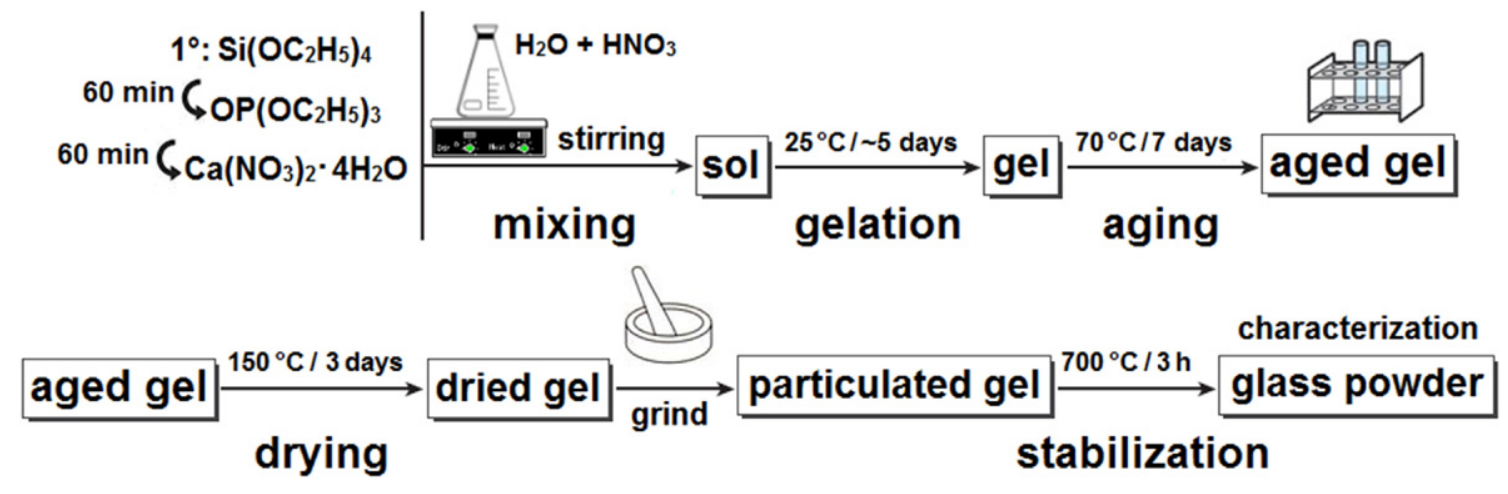

Fig. 1. Flowchart of the steps involved in preparing the particulate gel-glasses. 
Table 1

Ionic concentration of the SBF proposed for the evaluation of in vitro bioactivity versus human blood plasma.

\begin{tabular}{lllllllll}
\hline $\begin{array}{l}\text { Simulated body fluid } \\
\text { (SBF) }\end{array}$ & \multicolumn{7}{l}{ Ionic concentration $(\mathrm{mmol} / \mathrm{L})$} \\
\cline { 2 - 8 } ISO/FDI 23317 (2007) & $\mathrm{Na}^{+}$ & $\mathrm{K}^{+}$ & $\mathrm{Mg}^{2+}$ & $\mathrm{Ca}^{2+}$ & $\mathrm{Cl}^{-}$ & $\mathrm{HCO}_{3}^{-}$ & $\mathrm{HPO}_{4}^{2-}$ & $\mathrm{SO}_{4}^{2-}$ \\
\hline${ }^{\mathrm{a} S B F}$ & 142.0 & 5.0 & 1.5 & 2.5 & 147.8 & 4.2 & 1.0 & 0.5 \\
Human blood plasma & 142.0 & 5.0 & 1.5 & 2.5 & 103.0 & 27.0 & 1.0 & 0.5 \\
\hline
\end{tabular}

a Buffer: tris(hydroxymethyl)aminomethane (TRIS).

signed a consent form approved by the ethics committee of UFRGS and by the Brazilian Platform Committee for Ethics and Research (CAAE 36403514.6.0000.5347). Fresh dental pulp was harvested from deciduous teeth in resorption, and mesenchymal stem cells were isolated as described previously $[16,17]$. The dental pulp of 4 different teeth were extracted and the cells maintained at $37^{\circ} \mathrm{C}$ in a humidified atmosphere containing $5 \% \mathrm{CO}_{2}$ in an MSC culture medium, consisting of $2.5 \mathrm{~g} / \mathrm{L}$ Hepes, pH 7.2 supplemented with $10 \%$ heat-inactivated FBS, $100 \mathrm{U} / \mathrm{mL}$ penicillin, $100 \mu \mathrm{g} / \mathrm{mL}$ streptomycin and $0.25 \mu \mathrm{g} / \mathrm{mL}$ amphotericin until reached the 6th passage for characterization and use in the experiments. Cell characterization was performed by morphological analysis of the cell cultures, differentiation assay in vitro and immunophenotypic profile using flow cytometry [16-18].

\subsubsection{Measurement of cell viability using the MTT assay}

Prior to testing, the bioactive glasses were subjected to $180^{\circ} \mathrm{C}$ for $4 \mathrm{~h}$ in an oven for sterilization. After characterization as mesenchymal stem cells, the cells were seeded in 96 -well culture plates $\left(7 \times 10^{3}\right.$ cells/well $)$ and treated with glass powders in culture medium at concentrations of $0.125,1.25,12.50$ and $125.00 \mathrm{mg} / \mathrm{mL}$. After 2 and 7 days of treatment with the BG-A and BG-B compositions, cell viability was evaluated by the 3-(4,5-dimethylthiazol-2-yl)-2,5-diphenyltetrazolium bromide (MTT) reduction [19]. Cells were incubated with $200 \mu \mathrm{L}$ of $0.25 \mathrm{mg} / \mathrm{mL}$ MTT, and $4 \mathrm{~h}$ later, the supernatant was carefully removed and dimethyl sulfoxide (DMSO, $250 \mu \mathrm{L}$ ) was added to each well to dissolve the formed crystals. Next, $200 \mu \mathrm{L}$ of the colored solution was transferred for absorbance analysis at 570 and $630 \mathrm{~nm}$ in the molecular devices SpectraMax® 250 Microplate Spectrophotometer - the results were calculated by the absorbance label subtraction. Because the MTT is a colorimetric assay and the glasses release color, tests without cells were performed using only materials and reagents. The absorbance values obtained in these tests were subtracted from the values obtained in the tests with cells to eliminate any interference.

\subsubsection{Quantification of calcium and phosphorus in the cell culture supernatant}

To quantify calcium and phosphorus released, aliquots of the supernatant of the cell cultures treated with different concentrations of the BG-A and BG-B compositions were quantified after 2 and 7 days using different kits: Ca Arsenazo Liquiform Ref. 95 and Phosphorus UV Ref. 12 (Labtest Diagnóstica SA), and Ca-Color Arsenazo III Ref. 1009606 and Fosfatemia UV Ref. 1009614 (Wiener Lab). Measurements were performed with a 560 Labmax (Labtest Diagnóstica SA) and Wiener Lab CMD800i X1 analyzers.

\subsection{Bacterial test}

The S. mutans strain (ATCC 25175) was diluted to the 0.5 McFarland turbidity standard $\left(1 \times 10^{8} \mathrm{CFU} / \mathrm{mL}\right)$, and the solution was then further diluted with B.H.I. broth (BD Bioscience) to the ratio of 1:100, yielding a final concentration of $10^{6} \mathrm{CFU} / \mathrm{mL}$. For the test, glass powders were compressed into discs $(10 \times 2.2 \mathrm{~mm})$ by isostatic pressing at $170 \mathrm{MPa}$. Biofilms were formed over $(n=18)$ sterile discs and placed in 24well culture plates with $1 \%$ sucrose, $1.0 \mathrm{~mL}$ broth and $0.1 \mathrm{~mL}$ bacterial inoculum. Subsequently, the cell culture plates were incubated without interruption in an anaerobic chamber for 7 days at $37^{\circ} \mathrm{C}$. After this period of growth, the biofilms over the bioactive glass discs were transferred to the second 24 well-plate containing PBS and washed to remove any loosely bound material. Then, the discs were transferred to a falcon tube containing $5 \mathrm{~mL}$ PBS and subjected to an ultrasonic homogenizer to disperse the biofilm [20,21]. From the obtained solution, serial dilutions were performed, in which $0.1 \mathrm{~mL}$ aliquots were plated in triplicate on B.H.I. agar (BD Biosciences) using the drop technique. The bacteria culture was incubated at $37{ }^{\circ} \mathrm{C}$ and $5 \% \mathrm{CO}_{2}$. After $48 \mathrm{~h}$, the number of $\mathrm{CFU} / \mathrm{mL}$ for each sample was counted and transformed into logarithm scale $(\log 10)$.

\subsection{Statistical analysis}

The results were expressed as the mean \pm standard error of the mean from 3 and 4 independent experiments for the BG-A and BG-B composition, respectively, and evaluated using the Kruskal-Wallis and Dunn's post hoc test. Significant differences were established at $p<0.05$. Statistical analysis was performed using Bioestat 5.0 software [22].

\section{Results and discussion}

\subsection{Materials characterization and in vitro bioactivity}

The BG-A and BG-B gels presented a gelation time of approximately 90 and $150 \mathrm{~h}$, respectively. After drying, these gels were transparent, colorless and optically homogeneous, as shown in Fig. 2.

Heat treatment of the gel particles for $3 \mathrm{~h}$ at $700{ }^{\circ} \mathrm{C}$ provided a sufficient condition to obtain the glasses because it was not possible to observe any evidence of sub-products from the incomplete condensation of precursors and nitrate ions in the XRD patterns and FTIR spectra of the samples, as shown in Figs. 3-5, respectively. The XRD patterns of the samples before immersion in SBF were typical of amorphous materials, characterized by a broad halo centered at $\sim 25^{\circ}(2 \theta)$, which is a typical feature of silicate glasses; however, the XRD pattern of the BG-A composition exhibited a broad peak centered at $\sim 32^{\circ}(2 \theta)$. This peak can be attributed to the presence of hydroxyapatite (HA), the intensity of which is not sufficiently strong to establish the extent of the sorting feature for this phase. It was also identified in samples of the $\mathrm{SiO}_{2}-$ $\mathrm{CaO}-\mathrm{P}_{2} \mathrm{O}_{5}$ system with similar compositions $[12,13,23]$.

XRD patterns obtained for the glasses after $12 \mathrm{~h}$ in contact with SBF showed two principal peaks at approximately 26 and $32^{\circ}(2 \theta)$, corresponding to (002) and (121) atomic plane diffraction of the HCA-like phase. The association is made with HCA because the formation of pure hydroxyapatite (HA) on the surface of the glasses is less likely to occur in SBF. This solution contains a quantity of bicarbonate ions $\left(\mathrm{HCO}_{3}^{-}\right)$and the $\mathrm{HA}$ is saturated with slightly carbonated apatite, where the orthophosphates are substituted by carbonates in the crystal

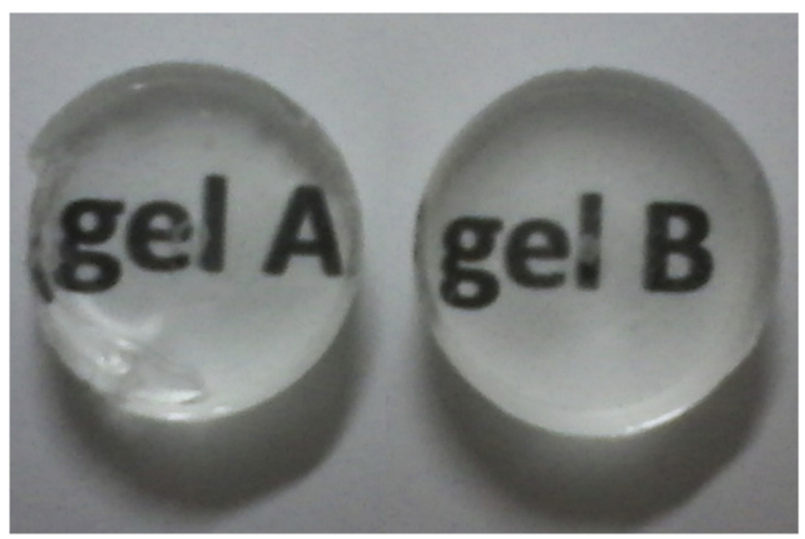

Fig. 2. Illustration of the BG-A and BG-B gels after drying. 

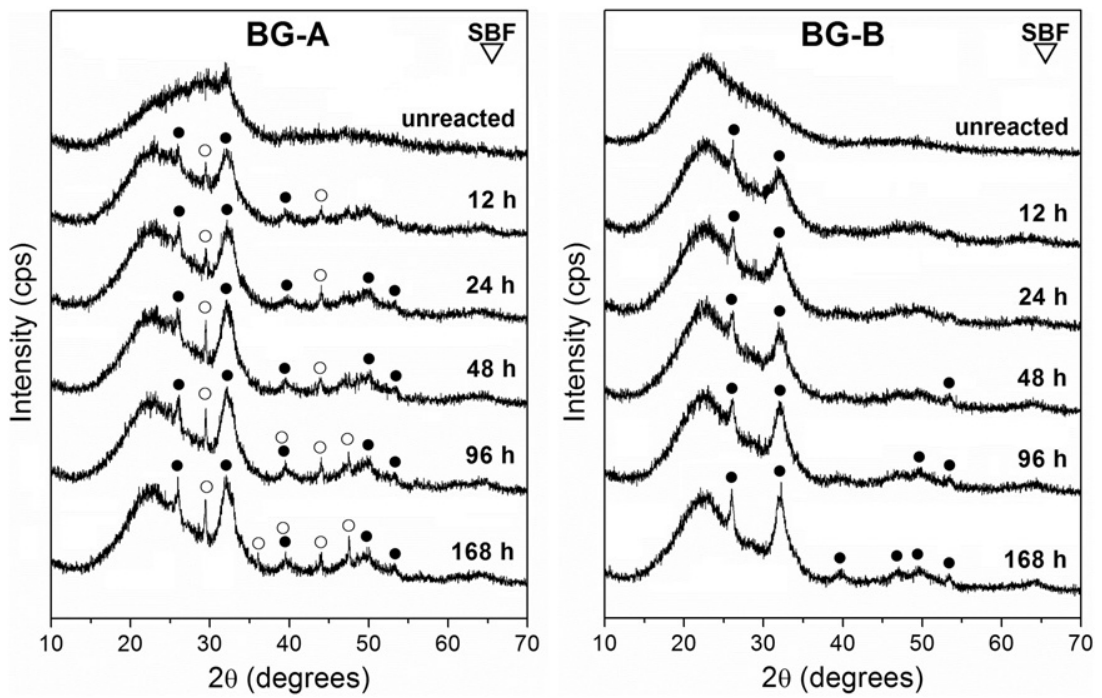

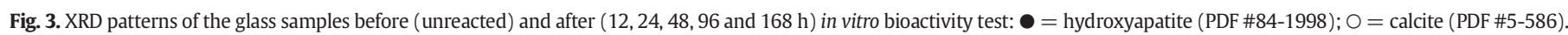

lattice $[15,24]$. In both samples, these peaks increase and sharpen with increasing testing time, up to $168 \mathrm{~h}$. At the same time, new broad peaks appear at approximately $40,47,50$ and $53^{\circ}(2 \theta)$, corresponding to the (310), (113), (123) and (004) atomic planes in the HCA lattice, respectively, which are correlated to the increased crystallinity. Although the main phase formed on the surface of the glasses is HCA, it was also possible to observe the formation of calcium carbonate (calcite) starting from $12 \mathrm{~h}$ in SBF for the sample with higher calcium contents (BG-A). Previous studies have also reported this finding for similar compositions [15,25-27].

The presence of calcium-phosphate deposition on the surface of the glass particles, such as HCA, was also observed using FTIR analysis. In the spectra shown in Figs. 4 and 5, phosphate bands at 605 and $565 \mathrm{~cm}^{-1}$ ( $\mathrm{P}-\mathrm{O}$ bending), indicating HCA formation, are present for the glass exposed to SBF [12-14,23,27]. These bands became more defined with increased reaction time, particularly for the BG-A composition, indicating greater HCA density on the glass surfaces with advancing stages of crystallization, as observed in the XRD patterns shown in Fig. 3. Bands characteristic of the carbonate group $\left(\mathrm{CO}_{3}^{2-}\right)$ were detected at 1390 and $875 \mathrm{~cm}^{-1}$ in both spectra. However, for the BG-B composition, it was only possible to observe the presence of $\mathrm{CO}_{3}^{2-}$ after immersion of the samples in SBF for $168 \mathrm{~h}$ (not pronounced bands), which is consistent with the absence of calcite on the surface of these samples, as observed in the XRD patterns. To conclude, the differences in the intensity of the $\mathrm{Si}-\mathrm{O}-\mathrm{Si}$ stretch band near $1100 \mathrm{~cm}^{-1}$ can be attributed to the different amount of silica (60 versus $80 \mathrm{~mol} \%$ ) in the glasses.

In Figs. 4 and 5, the morphology of the sample surfaces changed significantly after various immersion times in SBF. Consequently, the surface of the powders was converted to a mixed poly-crystalline HCA layer equivalent to the crystal phase of bone mineral with an anisotropy that also mimicked the architecture of mineralized bone [2,5]. The HCA formation promoted powder clustering, leaving the larger particles in the center of these granules, as shown in Fig. 6 for the BG-A. After $48 \mathrm{~h}$ of testing, all of the samples showed the typical morphology of
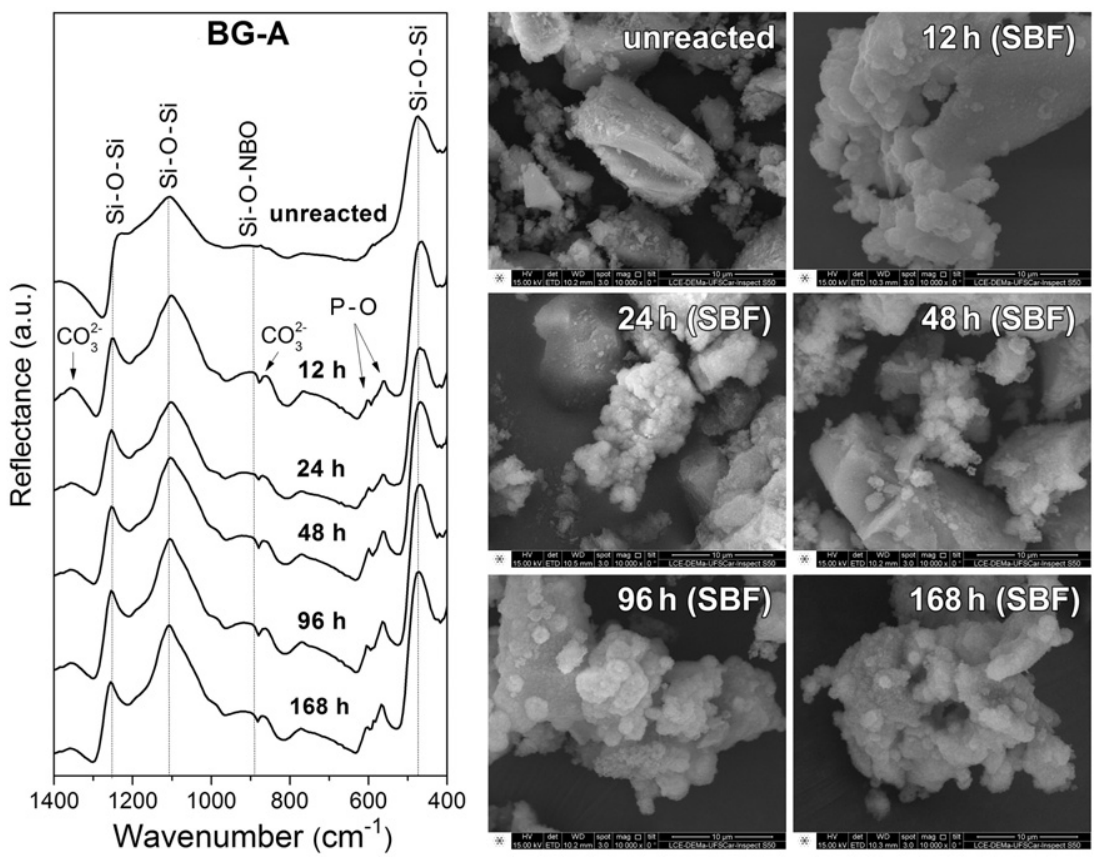

Fig. 4. FTIR spectra and SEM micrographs of BG-A before (unreacted) and after (12, 24, 48, 96 and 168 h) in vitro bioactivity test. 

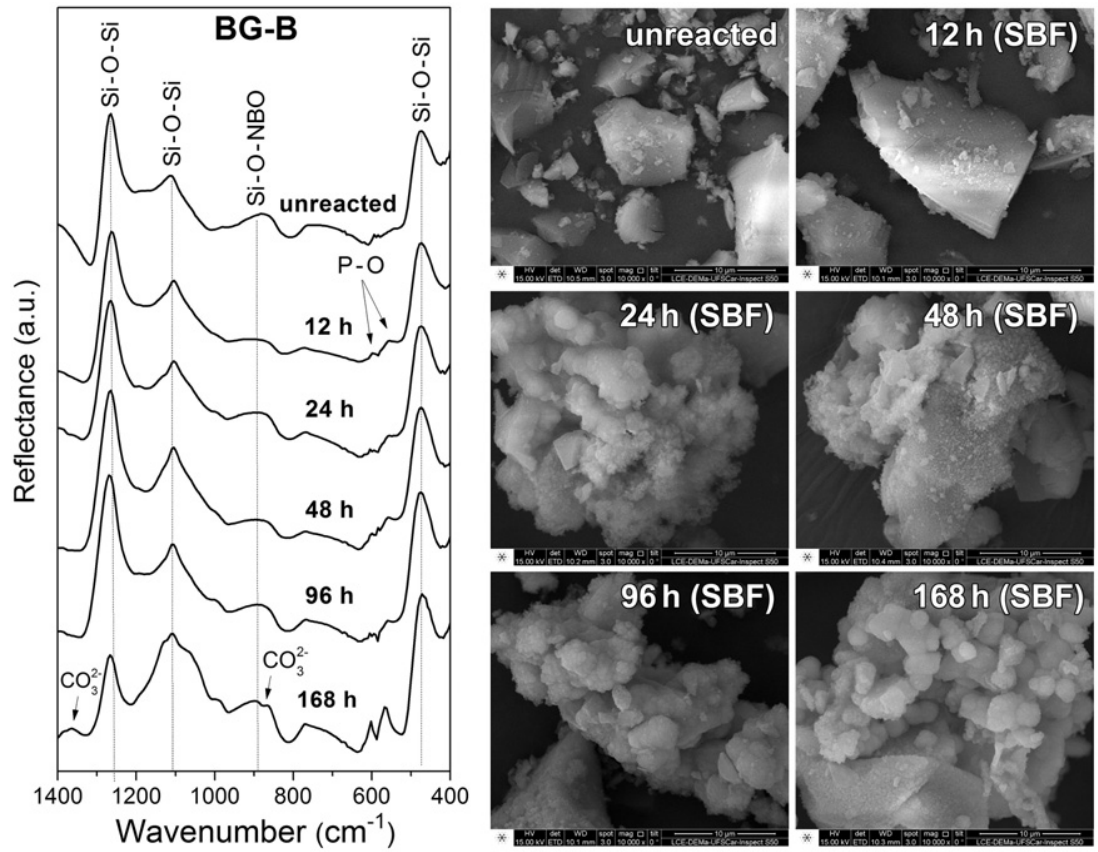

Fig. 5. FTIR spectra and SEM micrographs of BG-B before (unreacted) and after (12, 24, 48, 96 and $168 \mathrm{~h}$ ) in vitro bioactivity test.

HCA, and it was no longer possible to observe the glass surface. As observed in the EDS spectra for both glass powders, there was a large compositional change of the surface at different testing times; the surface compositions were characterized by a predominance of $\mathrm{Ca}$ and $\mathrm{P}$, which further confirmed HCA layer formation.

Variations in $\mathrm{pH}$ at different exposure times to the samples in SBF are presented in Fig. 7; the initial $\mathrm{pH}$ value of the solution was 7.4. The compositions of BG-A and BG-B presented distinct trends in $\mathrm{pH}$ variation; i.e., the $\mathrm{pH}$ increased very fast for BG-A up to $24 \mathrm{~h}$ and remained nearly constant at approximately 8.35 until the last testing time of $168 \mathrm{~h}$. For $\mathrm{BG}-\mathrm{B}$, the $\mathrm{pH}$ increased slowly up to 7.70 and remained nearly constant. Thus, by comparing the $\mathrm{pH}$ variation during the in vitro bioactivity test, it was possible to observe that the most abrupt change occurred for the BG-A composition in the first few hours. In addition, the lowest $\mathrm{pH}$ variation was observed for the BG-B composition, indicating that the solubility of this glass was lower compared to the other because the $\mathrm{pH}$
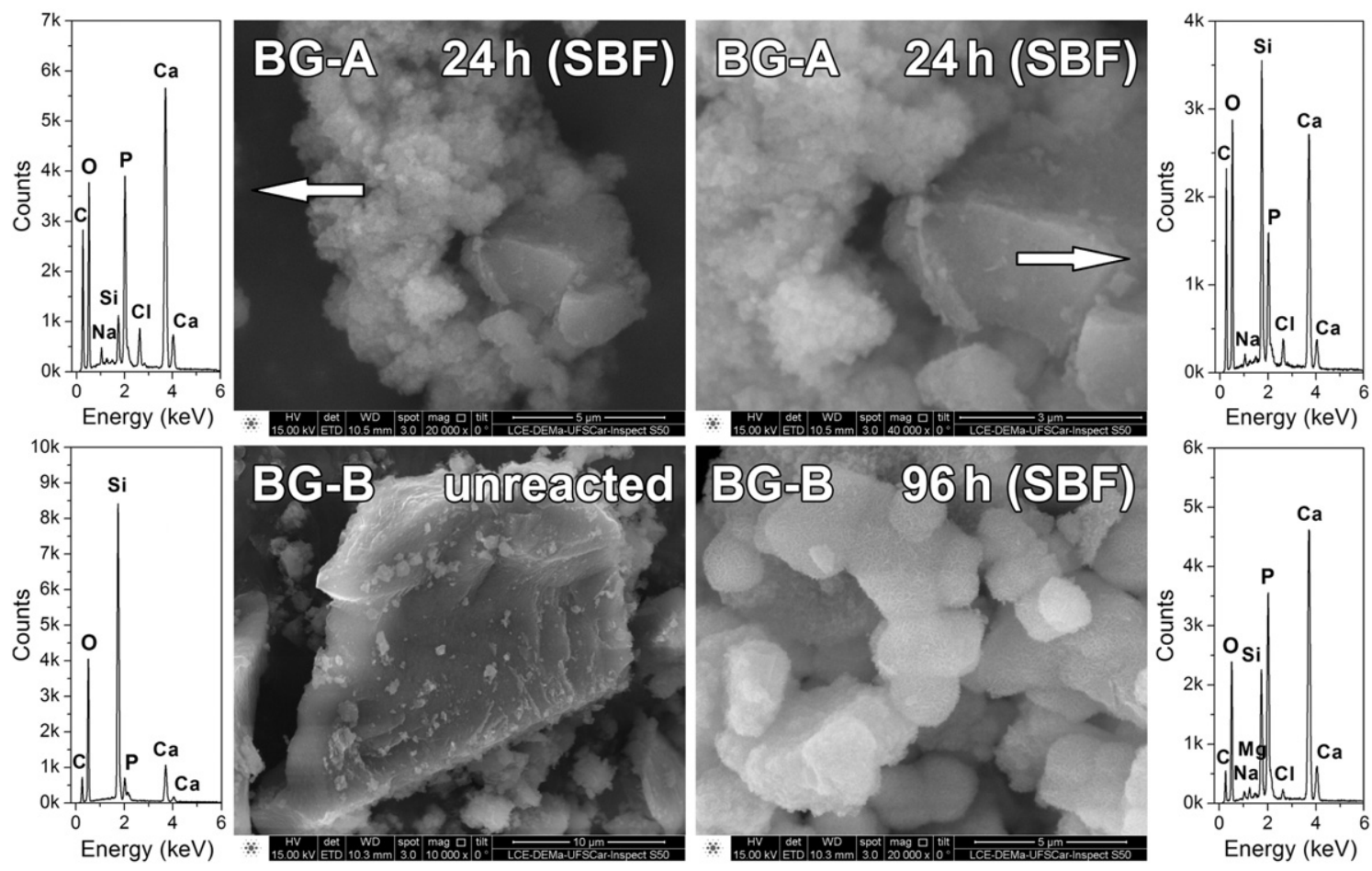

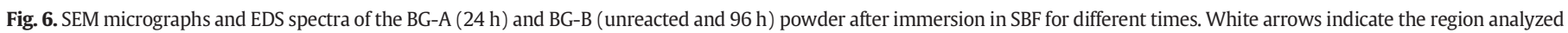
by EDS. 


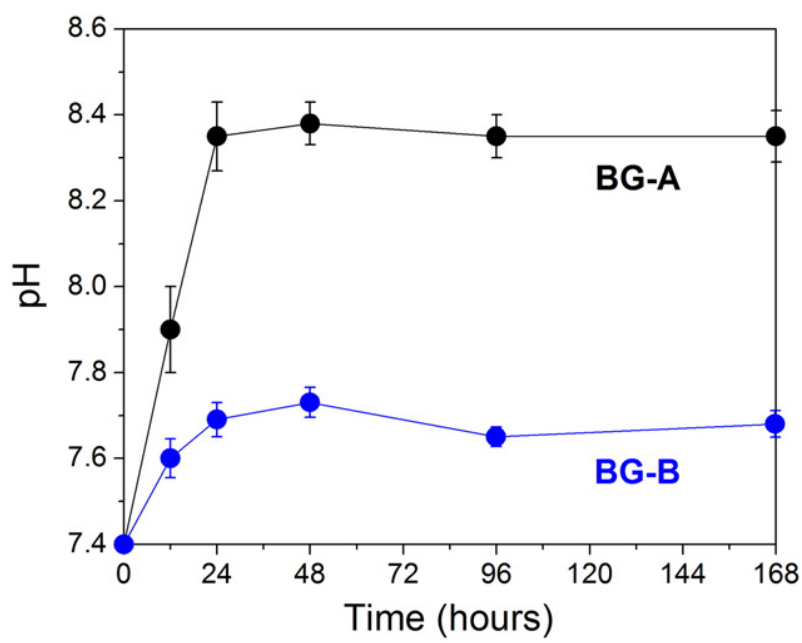

Fig. 7. Variations in $\mathrm{pH}$ versus immersion time in SBF.

variation exhibited a direct relationship with cation exchange from the glass with protons $\left(\mathrm{H}^{+}\right)$from the solution $[12,15,27]$, such as calcium released into the media.

The lower $\mathrm{SiO}_{2}$ content and concentration of calcium of the BG-A composition produced a more pronounced HCA layer within the first few hours of testing and at the same time, provided a higher $\mathrm{pH}$ of the $\mathrm{SBF}$. However, the BG-B composition also showed a positive in vitro bioactive response but maintained a more stable $\mathrm{pH}$ environment. Thus, it is important to note that it is possible to maintain bioactive behavior while providing a more stable local microenvironment by varying the composition of the material and, consequently, its degradability. The biological effects of the $\mathrm{pH}$ change that the material can provide in the body are a matter of concern [5,28-33], and more specific studies in this field are necessary.

\subsection{Characterization of mesenchymal stem cells}

Cells from human exfoliated deciduous teeth were isolated, cultured and successfully characterized as MSCs, according to the International Society for Cellular Therapy (ISCT) using the 3 following standard criteria [18]: 1) The cells showed typical MSC morphology and plasticadherence when maintained in standard culture conditions (Fig. 8A); 2) MSCs must positively express ( $\geq 95 \%)$ CD105 (endoglin), CD73 (ecto-5'-nucleotidase) and CD90 (Thy1), and negatively express ( $\leq 2 \%)$ CD34, CD45, CD14 or CD11b and HLA-DR surface molecules. Flow cytometric analyses demonstrated a typical pattern for MSC surface markers, positively expressing CD73 (100\%), CD90 (99.5\%) and CD105 (97.8\%), and negatively expressing CD14, CD34, CD45 and HLA-DR $(0 \%) ; 3)$ The MSCs must also differentiate into osteoblasts, adipocytes and chondroblasts in vitro. The cells studied differentiated into the 3 analyzed mesodermal cell lineages. Chondrogenic differentiation was demonstrated by staining with Alcian Blue, as indicated by the blue staining of glycosaminoglycan deposits (Fig. 8B). Osteogenic differentiation was demonstrated by staining with Alizarin Red in which calcium deposits were indicated by red staining (Fig. 8C). Adipogenic differentiation was demonstrated by staining with Oil Red $\mathrm{O}$ to visualize lipid vacuoles (Fig. 8D).

\subsection{Effects of the bioactive glasses on stem cell viability}

MTT reduction in live cells by mitochondrial reductase resulted in the formation of formazan, as detected by a higher absorbance in viable cells [19]. Thus, the results in Fig. 9 show that in concentrations ranging from 0.125 to $12.50 \mathrm{mg} / \mathrm{mL}$, the BG-A composition did not affect cell viability after 2 days of cultivation. The absorbance values were compared to the control $(p<0.05)$. A statistically significant difference was

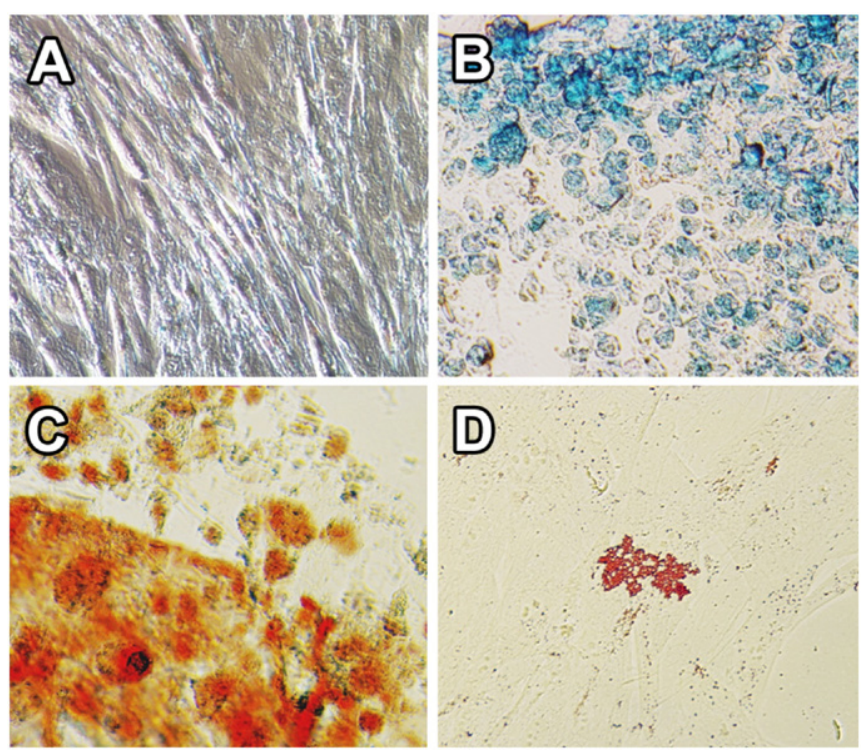

Fig. 8. Trilineage mesenchymal differentiation potential of MSCs: A) Morphological appearance of undifferentiated MSCs (control); B) Chondrogenic differentiation demonstrated by glycosaminoglycans stained with Alcian Blue; C) Osteogenic differentiation evidenced by calcified matrix stained with Alizarin Red; and D) Adipogenic differentiation indicated by droplets of fat, highlighted by Oil Red. Microphotographs at $400 \times$ magnification.

observed between the control and the higher concentration $(125.00 \mathrm{mg} / \mathrm{mL})$ after 2 days, indicating the presence of more viable stem cells. However, after 7 days of culture, the BG-A-treated group with 12.50 and $125.00 \mathrm{mg} / \mathrm{mL}$ showed that cell viability was significantly suppressed $(p<0.05)$. Lower doses $(0.125$ and $1.25 \mathrm{mg} / \mathrm{mL})$ did not affect cell viability in 2 and 7 days of culture, compared to the control $(p>0.05)$. These findings suggested that the BG-A group at $125 \mathrm{mg} / \mathrm{mL}$ is capable of increasing stem cell viability after 2 days of cultured, but reduced cell viability after 7 days.

Cell viability was dose-dependent on bioactive glasses. For instance, extracts prepared from the same glass composition ( 3 and $5 \mathrm{mg} / \mathrm{mL}$ ) were effective at inducing murine and human primary osteoblast proliferation [34]. However, doses higher than $5 \mathrm{mg} / \mathrm{mL}$ were increasingly inhibitory for cell proliferation in both species at 2, 4 and 6 days of evaluation. The glass-conditioned medium did not inhibit the proliferation of murine osteoblasts at any time, but the effects on human osteoblasts varied. Proliferation was inhibited on day 2 , stimulated on day 4 ,

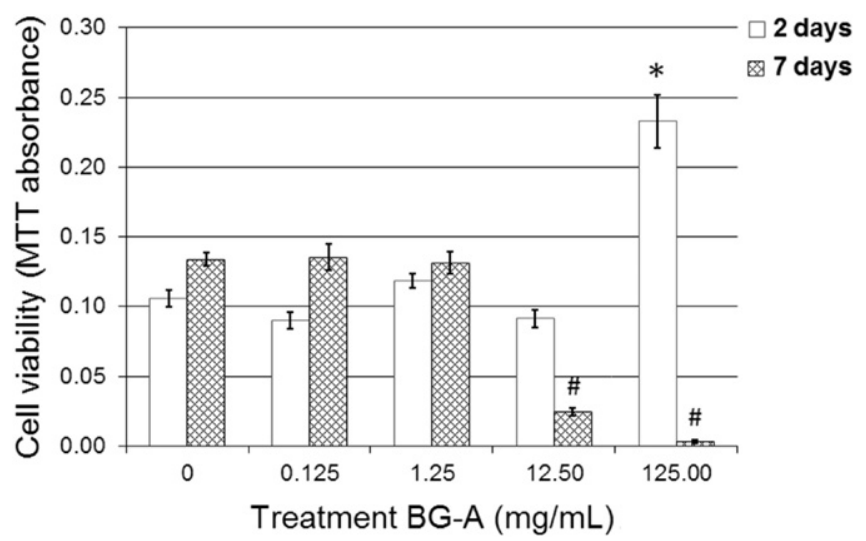

Fig. 9. Effects of BG-A on stem cell viability by MTT assay. Data are expressed as the mean \pm standard error of the mean of 3 independent experiments. $\left({ }^{*}\right)$ indicates higher viability related to the control values after 2 days $(p<0.05)$ and $\left({ }^{\#}\right)$ indicates lower viability related to the control values after 7 days $(p<0.05)$. Statistical analysis was performed using the Kruskal-Wallis and Dunn's post hoc test. 
and more strongly inhibited on day 6. Consequently, it can be concluded that the composition and dissolution rate of the bioactive glass and the cell type used in the assay are important factors to be considered. More recently, Ajita et al. [35] showed that nanoparticles of a $45 \mathrm{SiO}_{2}-40 \mathrm{CaO}-$ $15 \mathrm{P}_{2} \mathrm{O}_{5}$ (mol\%) bioactive glass did not affect cell viability (mouse mesenchymal stem cells) up to a concentration of $20 \mathrm{mg} / \mathrm{mL}$. However, the sample demonstrated a stimulatory effect on metabolic activity at a concentration of $20 \mathrm{mg} / \mathrm{mL}$ after $48 \mathrm{~h}$ of treatment. When used at a concentration higher than $20 \mathrm{mg} / \mathrm{mL}$, cytotoxicity was revealed, as observed by the decreased optical density (OD) values using the MTT assay.

The results of the BG-B composition are shown in Fig. 10. After 2 days, this glass showed a significant difference at all doses compared with untreated cells. Treatment with doses of $0.125,1.25$ and $12.50 \mathrm{mg} / \mathrm{mL}$ resulted in greater cell viability and the dose of $125.00 \mathrm{mg} / \mathrm{mL}$ resulted in a lower cell viability compared with the control $\left({ }^{*} p<0.05\right)$. It is possible to observe a dose-dependent effect of the BG-B composition on cell behavior after 2 days. After 7 days of culture, doses of $1.25,12.50$ and $125.00 \mathrm{mg} / \mathrm{mL}$ showed lower viability compared to the control group and the dose of $0.125 \mathrm{mg} / \mathrm{mL}\left({ }^{\#} p<0.05\right)$.

Quantification of calcium and phosphorus in the supernatant of the cell cultures treated with different concentrations of the BG-A and BG-B compositions are shown in Figs. 11 and 12, respectively. The calcium concentration was increased after 2 days of culture with BG-A at $125.00 \mathrm{mg} / \mathrm{mL}(p<0.05)$ and decreased after 7 days of culture at $12.50 \mathrm{mg} / \mathrm{mL}(p<0.05)$. No significant differences were found in the supernatant of cells treated with BG-B composition on any of the days analyzed.

Although differences were found in the BG-A-conditioned medium at concentrations of 12.50 and $125.00 \mathrm{mg} / \mathrm{mL}$ for 7 and 2 days, respectively, in general, it was not possible to observe a significant variation of calcium in the supernatant of the cell cultures treated with different concentrations of samples. This finding can be attributed to the presence of proteins in the FBS used in the medium for maintenance of the cells. Proteins are charged species that can be attracted by the negative glass surface (and coat it with a film), resulting in lower dissolution rates and bioactivity [36-38]. Consequently, the effect of $\mathrm{pH}$ variation provided by the samples (see Fig. 7) could not be evaluated in the cell culture medium for at least two reasons. First, because the $\mathrm{pH}$ change is related to the exchange of calcium ions from the glass with $\mathrm{H}^{+}$ions from the medium, as previously described. However, as shown in Fig. 11 , there was practically no variation in calcium compared to the control group, which could be attributed to the presence of FBS. In addition, the $\mathrm{pH}$ is stabilized due its relationship with the experimental conditions of MSC cultures in vitro. For a better reproduction of the in vivo

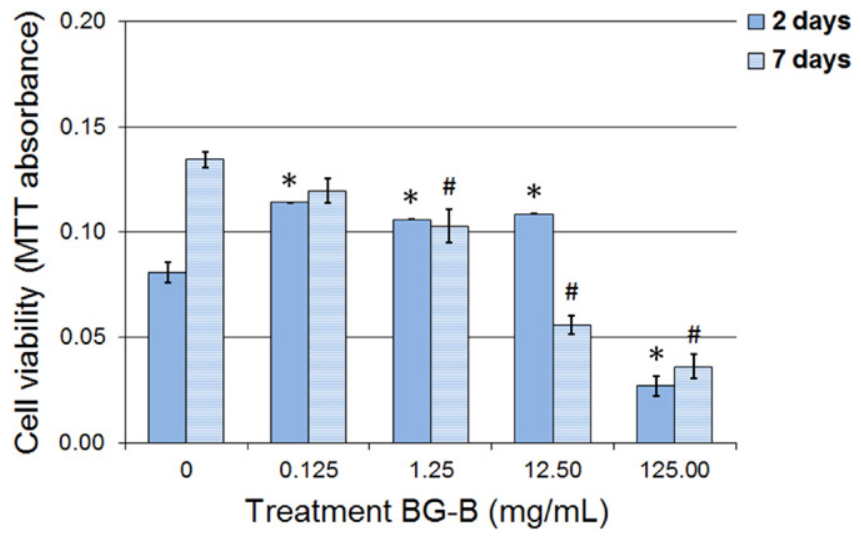

Fig. 10. Effects of BG-B on stem cell viability by MTT assay. Data are expressed as the mean \pm standard error of the mean of 4 independent experiments. $\left({ }^{*}\right)$ indicates higher viability related to the control values after 2 days $(p<0.05)$ and $\left({ }^{\#}\right)$ indicates lower viability related to the control values after 7 days $(p<0.05)$. Statistical analysis was performed using the Kruskal-Wallis and Dunn's post hoc test.

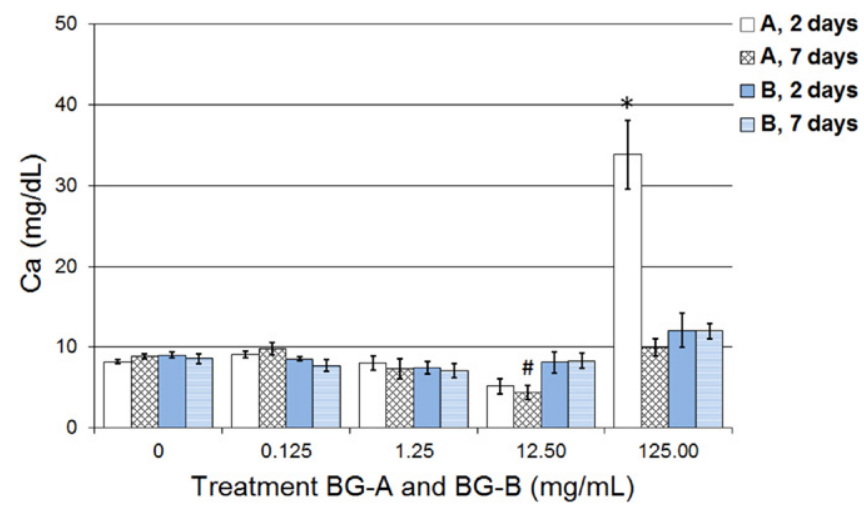

Fig. 11. Calcium concentration in the stem cell supernatant after 2 and 7 days. Data are expressed as the mean \pm standard error of the mean of 3 (BG-A) and 4 (BG-B) independent experiments. $\left({ }^{*}\right)$ indicates higher $\mathrm{Ca}$ concentration differences in relationship to the control values after 2 days $(p<0.05)$ and $\left({ }^{\#}\right)$ indicates lower $\mathrm{Ca}$ concentration in relationship to the control values after 7 days $(p<0.05)$. Statistical analysis was performed using the Kruskal-Wallis and Dunn's post hoc test.

environment, a cell culture test was performed in a $37^{\circ} \mathrm{C}$ incubator in a humidified atmosphere of $95 \%$ air and $5 \% \mathrm{CO}_{2}$, the system $\mathrm{pH}$ of which was adjusted to constant values during the experiment. This condition is different from that used to mediate the apatite-forming ability of bioactive glass, making the biological effects of these changes difficult to predict from in vitro experiments.

The quantification of phosphorus showed a decrease of this species in the culture medium treated with the BG-A composition at 1.25, 12.50 and $125.00 \mathrm{mg} / \mathrm{mL}(p<0.05)$. For the culture treated with the $\mathrm{BG}-\mathrm{B}$, a significant difference compared to the control was only observed at a concentration of $125.00 \mathrm{mg} / \mathrm{mL}$ for 2 days $(p<0.05)$. This result showed a correlation with the bioactivity test because phosphorous is released from the samples to the medium and subsequently migrates to the particle surfaces to form a HCA layer. However, its concentration is low in both glasses, and it appears that the rate of HCA formation is higher than the rate of phosphorous release from the samples [12], resulting in a decrease of this species in the culture medium during the test. This behavior is more pronounced for the BG-A composition, which is consistent with the higher HCA layer formation rate shown in Figs. 3-5. The BG-B composition is more stable, providing a better condition for cell proliferation, as indicated by the previous discussed results shown in Figs. 9 and 10.

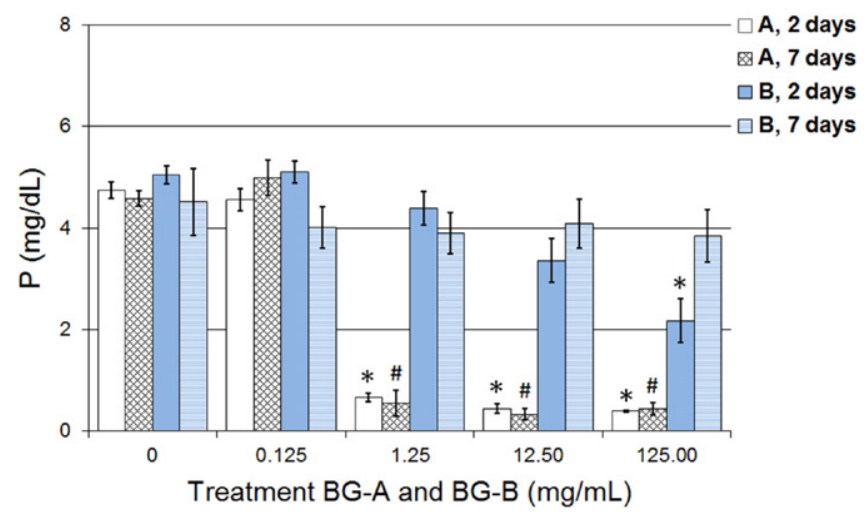

Fig. 12. Phosphorus concentration in the stem cell supernatant after 2 and 7 days. Data are expressed as the mean \pm standard error of the mean of 3 (BG-A) and 4 (BG-B) independent experiments. $\left.{ }^{*}\right)$ indicates lower $\mathrm{P}$ concentration differences in relationship to the control values after 2 days $(p<0.05)$ and $\left({ }^{\#}\right)$ indicates lower P concentration in relationship to the control values after 7 days $(p<0.05)$. Statistical analysis was performed using the Kruskal-Wallis test and Dunn's post hoc test. 

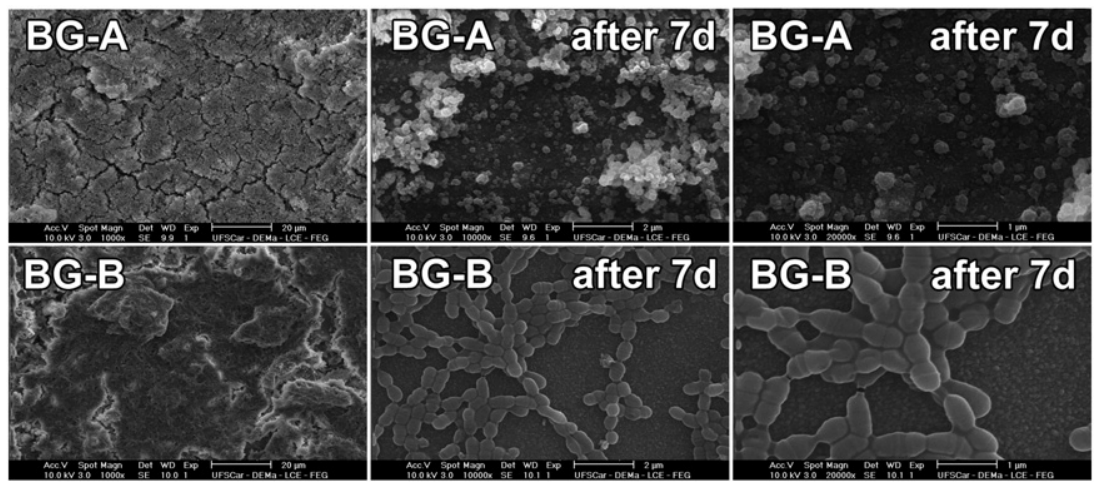

Fig. 13. SEM micrographs of the BG-A (above) and BG-B (down) discs before and after S. mutans biofilm induced over the surface for 7 days.

\subsection{Effects of the bioactive glasses on biofilm viability}

The antibacterial activity of the BG-A and BG-B compositions against S. mutans was evaluated and showed a significant effect. There was no bacterial growth after $\mathrm{CFU} / \mathrm{mL}$ testing of 7 days of biofilm induction $(p<0.05)$. However, on the SEM images for the BG-B composition (Fig. 13), it was possible to observe that a biofilm formed on the disc surfaces.

The effect of bioactive glasses (without any specific bactericidal ions) on biofilm viability observed in this study can be mainly explained by the release of ions from the samples to the medium, causing an increase in the osmotic pressure and raises $\mathrm{pH}$ in the vicinity of the disc samples. These changes are considered important factors that destroy microorganisms [39-44]; however, the continuous release of ions from the samples it also affects the body's cells, thereby influencing regeneration. Obviously, the final effect is dependent on the glass composition, its textural properties and bacterial species. For example, the fast dissolution of the glasses changes the acid environment that aciduric cariogenic bacteria are dependent [45]. This dissolution and consequent abrupt $\mathrm{pH}$ change occurs within a short time period, as observed in Fig. 7 in relationship to the bioactivity test. In this case, it is important to note that the SBF is a buffer solution. Consequently, the $\mathrm{pH}$ can reach higher values in the oral environment containing saliva, which possesses a buffering capacity smaller than SBF.

The effect of increases in $\mathrm{pH}$ during the leaching and dissolution processes of the BG-A composition is also supported by SEM images shown in Fig. 13, which reveal no bacteria on the disc surfaces after day 7. However, SEM images of the BG-B displayed some bacteria stacks and chains covering the sample surfaces. Some holes or hollows of approximately $200 \mathrm{~nm}$ could be observed on the bacterial cell surfaces, potentially indicating small cell membrane damage. The BG-B composition contains a higher concentration of silica and lower amounts of calcium and phosphorus; consequently, it is more stable, thereby promoting a favorable environment for biofilm formation. This greater stability could be followed by the bioactivity test (see Fig. 7). Thus, it has become clear that only varying the composition of the samples can establish some control in the system degradability in the physiological medium and with direct application to favor specific properties, such as bioactivity, cell proliferation or antimicrobial activity.

\section{Conclusions}

Glasses containing $60 \mathrm{SiO}_{2}-36 \mathrm{CaO}-4 \mathrm{P}_{2} \mathrm{O}_{5}$ (BG-A) and $80 \mathrm{SiO}_{2}-$ $15 \mathrm{CaO}-5 \mathrm{P}_{2} \mathrm{O}_{5}$ (BG-B) by mol\% were prepared using a simple sol-gel processing route. Both samples are bioactive in SBF, but the BG-A composition showed a higher rate of hydroxycarbonate apatite layer formation. This is due to its lower concentration of silica and high amount of calcium than in the BG-B composition. For this test, the new method proposed by the TC04 for evaluating in vitro bioactivity was tested and considered quite satisfactory due to its ease of application and use of only a small amount of particulate sample.

The two glasses showed significant antibacterial effect against $S$. mutans, with the BG-A being more effective. Scanning electron micrographs showed no growth of bacteria on BG-A, but some stacks and chains remained on discs of BG-B. In the stem cell study, the BG-B showed significantly higher cell viability than the BG-A for the concentrations of $0.125,1.25$ and $12.50 \mathrm{mg} / \mathrm{mL}$ for 2 days. This result indicated that the solubility of the BG-A composition favored bioactivity and the antibiofilm effect, but its higher dissolution and, consequently, more ions released into the cell culture medium, appear inhibited cell proliferation.

Thus, by varying the composition of the bioactive glasses, it is possible to examine some relevant properties such as bioactivity, stem cell proliferation and antimicrobial/antibiofilm activity of the material, providing minimally invasive approaches and a foundation for future studies on bioactive glass applications with clinical relevance.

\section{Acknowledgments}

The authors are grateful to the Brazilian agencies São Paulo Research Foundation, FAPESP - project no. 2013/07793-6 (CeRTEV) for generous funding, and CNPq - project no. 140516/2013-1 for the scholarship granted to R.L. Siqueira.

\section{References}

[1] L.L. Hench, Bioceramics, J. Am. Ceram. Soc. 81 (1998) 1705-1728.

[2] J.R. Jones, Review of bioactive glass: from Hench to hybrids, Acta Biomater. 9 (2013) 4457-4486.

[3] V. Miguez-Pacheco, L.L. Hench, A.R. Boccaccini, Bioactive glasses beyond bone and teeth: emerging applications in contact with soft tissues, Acta Biomater. 13 (2015) $1-15$.

[4] L.L. Hench, The story of Bioglass ${ }^{\circledR}$, J. Mater. Sci.: Mater. Med. 17 (2006) 967-978.

[5] L.L. Hench, N. Roki, M.B. Fenn, Bioactive glasses: importance of structure and properties in bone regeneration, J. Mol. Struct. 1073 (2014) 24-30.

[6] A. Hoppe, N.S. Guldal, A.R. Boccaccini, A review of the biological response to ionic dissolution products from bioactive glasses and glass-ceramics, Biomaterials 32 (2011) 2757-2774

[7] I.D. Xynos, A.J. Edgar, L.D. Buttery, L.L. Hench, J.M. Polak, Gene-expression profiling of human osteoblasts following treatment with the ionic products of Bioglass 45S5 dissolution, J. Biomed. Mater. Res. 55 (2001) 151-157.

[8] L.L. Hench, Genetic design of bioactive glass, J. Eur. Ceram. Soc. 29 (2009) 1257-1265.

[9] A. Hoppe, A.R. Boccaccini, Biological impact of bioactive glasses and their dissolution products, Front. Oral Biol. Basel, Karger 17 (2015) 22-32.

[10] E. Munukka, O. Leppäranta, M. Korkeamäki, M. Vaahtio, T. Peltola, D. Zhang, L. Hupa, H. Ylänen, J.I. Salonen, M.K. Viljanen, E. Eerola, Bactericidal effects of bioactive glasses on clinically important aerobic bactéria, J. Mater. Sci.: Mater. Med. 19 (2008) 27-32.

[11] H. Shahoon, M. Niyakan, M. Behnami, M. Behnami, S. Shahbazi, R. Toori, Antibacterial effect of morphous (poly-crystalline) and amorphous (glass) nano-bioactive glass $45 S 5$ on Streptococcus mutans, J. Dent. Sch. 33 (2015) 138-144.

[12] R.L. Siqueira, E.D. Zanotto, The influence of phosphorus precursors on the synthesis and bioactivity of $\mathrm{SiO}_{2}-\mathrm{CaO}-\mathrm{P}_{2} \mathrm{O}_{5}$ sol-gel glasses and glass-ceramics, J. Mater. Sci.: Mater. Med. 24 (2013) 365-379. 
[13] R. Li, A.E. Clark, L.L. Hench, An investigation of bioactive glass powders by sol-gel processing, J. Appl. Biomater. 2 (1991) 231-239.

[14] G. Malavasi, L. Menabue, M.C. Menziani, A. Pedone, A.J. Salinas, M. Vallet-Regí, New insights into the bioactivity of $\mathrm{SiO}_{2}-\mathrm{CaO}$ and $\mathrm{SiO}_{2}-\mathrm{CaO}-\mathrm{P}_{2} \mathrm{O}_{5}$ sol-gel glasses by molecular dynamics simulations, J. Sol-Gel Sci. Technol. 67 (2013) 208-219.

[15] A.L.B. Maçon, T.B. Kim, E.M. Valliant, K. Goetschius, R.K. Brow, D.E. Day, A. Hoppe, A.R. Boccaccini, I.Y. Kim, C. Ohtsuki, T. Kokubo, A. Osaka, M. Vallet-Regí, D. Arcos, L. Fraile, A.J. Salinas, A.V. Teixeira, Y. Vueva, R.M. Almeida, M. Miola, C. VitaleBrovarone, E. Verné, W. Höland, J.R. Jones, A unified in vitro evaluation for apatiteforming ability of bioactive glasses and their variants, J. Mater. Sci.: Mater. Med. 26 (2015) 115-125.

[16] L. Bernardi, S.B. Luisi, R. Fernandes, T.P. Dalberto, L. Valentim, J.A.B. Chies, A.C.F. Medeiros, P. Pranke, The isolation of stem cells from human deciduous teeth pulp is related to the physiological process of resorption, J. Endod. 37 (2011) 973-979.

[17] J.M.M. Andrade, R. Biegelmeyer, R. Dresch, N. Maurmann, P. Pranke, A.T. Henriques, In vitro antioxidant and enzymatic approaches to evaluate neuroprotector potential of blechnum extracts without cytotoxicity to human stem cells, Pharmacogn. Mag. 12 (2016) 171-177.

[18] M. Dominici, K. Le Blanc, I. Mueller, I. Slaper-Cortenbach, F. Marini, D. Krause, R. Deans, A. Keating, D.J. Prockop, E.M. Horwitz, Minimal criteria for defining multipotent mesenchymal stromal cells. The International Society for Cellular Therapy position statement, Cytotherapy 8 (2006) 315-317.

[19] Y. Liu, D.A. Peterson, H. Kimura, D. Schubert, Mechanism of cellular 3-(4,5-dimethylthiazol-2-yl)-2,5-diphenyltetrazolium bromide (MTT) reduction, J. Neurochem. 69 (1997) 581-593.

[20] T.C. Paradella, C.Y. Koga-Ito, A.O. Jorge, In vitro antibacterial activity of adhesive systems on Streptococcus mutans, J. Adhes. Dent. 11 (2009) 95-99.

[21] C.A. Pereira, R.L. Romeiro, A.C. Costa, A.K. Machado, J.C. Junqueira, A.O. Jorge, Susceptibility of Candida albicans, Staphylococcus aureus, and Streptococcus mutans biofilms to photodynamic inactivation: an in vitro study, Lasers Med. Sci. 26 (2011) 341-348.

[22] M. Ayres, M. Ayres Jr., D.L. Ayres, A.S. Santos, BioEstat 5.0. Aplicações estatísticas nas áreas das ciências biológicas e médicas, $5^{\text {a }}$ ed. Instituto de Desenvolvimento Sustentável Mamirauá - IDSM/MCT/CNPq, 2007 (364p).

[23] S. Padilla, J. Román, A. Carenas, M. Vallet-Regí, The influence of the phosphorus content on the bioactivity of sol-gel glass ceramics, Biomaterials 26 (2005) 475-483.

[24] J.C. Elliot, Structure and Chemistry of the Apatites and Other Calcium Orthophosphates, Elsevier Science, Amsterdam, 1994.

[25] A. Martínez, I. Izquierdo-Barba, M. Vallet-Regí, Bioactivity of a $\mathrm{CaO}-\mathrm{SiO}_{2}$ binary glasses system, Chem. Mater. 12 (2000) 3080-3088.

[26] M. Vallet-Regí, J. Román, S. Padilla, J.C. Doadrio, F.J. Gil, Bioactivity and mechanical properties of $\mathrm{SiO}_{2}-\mathrm{CaO}-\mathrm{P}_{2} \mathrm{O}_{5}$ glass-ceramics, J. Mater. Chem. 15 (2005) 1353-1359.

[27] M. Cerruti, D. Greenspan, K. Powers, Effect of $\mathrm{pH}$ and ionic strength on the reactivity of Bioglass ${ }^{\circledR}$ 45S5, Biomaterials 26 (2005) 1665-1674.

[28] D.E. Day, J.E. White, R.F. Brown, K.D. McMenamin, Transformation of borate glasses into biologically useful materials, Glass Technol. 44 (2003) 75-81.

[29] W. Liang, C. Rüssel, D.E. Day, G. Völksch, Bioactive comparison of a borate, phosphate and silicate glass, J. Mater. Res. 21 (2006) 125-131.
[30] E.A.A. Neel, D.M. Pickup, S.P. Valappil, R.J. Newport, J.C. Knowles, Bioactive functional materials: a perspective on phosphate-based glasses, J. Mater. Chem. 19 (2009) 690-701.

[31] M.N. Rahaman, D.E. Day, B.S. Bal, Q. Fu, S.B. Jung, L.F. Bonewald, A.P. Tomsia, Bioactive glass in tissue engineering, Acta Biomater. 7 (2011) 2355-2373.

[32] Y. Zhu, Y. Zhang, C. Wu, Y. Fang, J. Yang, S. Wang, The effect of zirconium incorporation on the physiochemical and biological properties of mesoporous bioactive glasses scaffolds, Microporous Mesoporous Mater. 143 (2011) 311-319.

[33] M. Montazerian, B.E. Yekta, V.K. Marghussian, C.F. Bellani, R.L. Siqueira, E.D. Zanotto, Bioactivity and cell proliferation in radiopaque gel-derived $\mathrm{CaO}-\mathrm{P}_{2} \mathrm{O}_{5}-\mathrm{SiO}_{2}-\mathrm{ZrO}_{2}$ glass and glass-ceramic powders, Mater. Sci. Eng. C 55 (2015) 436-447.

[34] R.C. Bielby, I.S. Christodoulou, R.S. Pryce, W.J. Radford, L.L. Hench, J.M. Polak, Timeand concentration-dependent effects of dissolution products of 58S sol-gel bioactive glass on proliferation and differentiation of murine and human osteoblasts, Tissue Eng. 10 (2004) 1018-1026.

[35] J. Ajita, S. Saravanan, N. Selvamurugan, Effect of size of bioactive glass nanoparticles on mesenchymal stem cell proliferation for dental and orthopedic applications, Mater. Sci. Eng. C 15 (2015) 142-149.

[36] K.D. Lobel, L.L. Hench, In-vitro protein interactions with a bioactive gel-glass, J. SolGel Sci. Technol. 7 (1996) 69-76.

[37] S. Radin, P. Ducheyne, P. Berthold, S. Decker, Effect of serum proteins and osteoblasts on the surface transformation of a calcium phosphate coating: a physicochemical and ultrastructural study, J. Biomed. Mater. Res. 39 (1998) 234-243.

[38] J.T.Y. Lee, Y. Leng, K.L. Chow, F. Ren, X. Ge, K. Wang, X. Lu, Cell culture medium as an alternative to conventional simulated body fluid, Acta Biomater. 7 (2011) 2615-2622.

[39] P. Stoor, E. Söderling, J.l. Salonen, Antibacterial effects of a bioactive glass paste on oral microorganisms, Acta Odontol. Scand. 56 (1998) 161-165.

[40] P. Stoor, E. Söderling R. Grenman, Interations between bioactive glass S53P4 and the atrophic rhinitis-associated microorganism Klebsiella ozaenae, J. Biomed. Mater. Res. 48 (1999) 869-874.

[41] M. Zehnder, T. Waltimo, B. Sener, E. Söderling, Dentin enhances the effectiveness of bioactive glass S53P4 against a strain of Enterococcus faecalis, Oral Surg., Oral Med., Oral Pathol., Oral Radiol. Endod. 101 (2006) 530-535.

[42] M. Zehnder, G. Baumgartner, K. Marquardt, F. Paqué, Prevention of bacterial leakage through instrumented root canals by bioactive glass S53P4 and calcium hydroxide suspension in vitro, Oral Surg., Oral Med., Oral Pathol., Oral Radiol. Endod. 103 (2007) 423-428.

[43] M. Gubler, T.J. Brunner, M. Zehnder, T. Waltimo, B. Sener, W.J. Stark, Do bioactive glasses convey a disinfecting mechanism beyond a mere increase in $\mathrm{pH}$ ? Int. Endod. J. 41 (2008) 670-678.

[44] D. Zhang, O. Lepparanta, E. Munukka, H.M.K. Ylanen, E. Eerola, M. Hupa, L. Hupa, Antibacterial effects and dissolution behavior of six bioactive glasses, J. Biomed. Mater. Res. A 93 (2010) 475-483.

[45] Y.-T. Xu, Q. Wu, Y.-M. Chen, R.J. Smales, S.-Y. Shi, M.-T. Wang, Antimicrobial effects of a bioactive glass combined with fluoride or triclosan on Streptococcus mutans biofilm, Arch. Oral Biol. 60 (2015) 1059-1065. 